\title{
An Appraisal of Goal 7 of the Millennium Development Goals of the United Nations VIS-À-VIS the Implementation of the 2011 United Nations Environment Programme Report on the Environmental Assessment of Ogoni Land in Nigeria and the Activities of the Hydrocarbon Remediation Project
}

\author{
Dr. SYLVANUS ABILA, Ph.D \\ Senior Lecturer/Former Head of Department, Private and Property Law, Faculty of Law Niger Delta University, \\ Wilberforce Island, Bayelsa State, Nigeria
}

\begin{abstract}
The paper is an appraisal of goal 7 of the millennium development goals of the United Nations (MDGs) in the light of the purported ongoing implementation of the 2011 United Nations Environment Programme Report (UNEP) on the environmental assessment of Ogoni land in Nigeria being carried out by the Hydrocarbon Remediation Project (HYPREP). The paper argues that there exists a nexus between the particulars of the UNEP report, goal 7 of the MDGs and the urgent need on the part of HYPREP to timeously and properly work on the findings contained in the UNEP report on Ogoni land to avert further environmental degradations, massive deaths and other health challenges on the indigenous peoples of Ogoni land in Nigeria, west Africa. In achieving its aim, this paper adopts an admixture of the historical, comparative, empirical, the law and development approaches, in relevant areas. The paper is concluded and a set of recommendations made.

Keywords: Appraisal, Goal 7 of the Millennium Development Goals, United Nations, Implementation, United Nations Environment Programme Report (UNEP), Assessment, Ogoni land, Nigeria, Hydrocarbon Remediation Project (HYPREP).
\end{abstract}

DOI: $10.7176 / \mathrm{CER} / 12-2-04$

Publication date: February $29^{\text {th }} 2020$

\subsection{BACKGROUND:}

An assessment of the Millennium Development Goals of the United Nations (herein after referred to as MDGs) clearly embrace multidimensional efforts at both the international and national levels that were aimed at protecting the environment. ${ }^{1}$ As a preliminary point, there is a need to examine, in summary what MDG 7 encompasses. It is a moot point that goal 7 of the MDGs deals with: "Resilient Communities and Nations for Reduced Disaster Impact from Natural and Technological Hazards." Expatiating on the above goal, the United Nations International Strategy for Disaster Reduction (UNISDR) has defined "resilience" as "the ability of a system, community or society exposed to hazards to resist, absorb, accommodate to and recover from the effects of a hazard in a timely and efficient manner, including through the preservation and restoration of its essential basic structures and functions." From an environmental point of view, the argument has be made that "there are linkages between climate, disasters and poverty etc. Losses from disasters are increasing [around the globe daily] and climatic events [causing] a large percentage of disasters: windstorms, floods, hurricanes and droughts." 2 This paper seeks to interrogate, amongst other things, whether the Ogoni indigenous people qualify to be regarded as a "resilient community" given the level of environmental degradation foisted on the people and their land by the activities of multinational oil companies in Nigeria, which they cope with, per day. In considering a resilient community therefore, informed discussion around the globe are almost in agreement that reference or recognition needs to be made in defining such a concept to a community "that is able to prepare for, adapt to and live through such shocks, while preserving its basic assets." It is summited that the Ogoni indigenous people fails squarely to the model of the conception of a "resilient community." While it is conceded that "the criteria that make communities resilient differ from place to place, in seeking a common understanding of the concept of resilience and in determining whether exists in the context of any national or cultural meliu, "its meaning has to be adapted at local levels and translated into concrete, specific indicators for each community." 3

This is perhaps why it is has been vigorously argued, justifiably, we submit, that MDG 7 was formulated to ensure environmental sustainability in recognition of a growing concern about current consumption and production patterns leading to an unsustainable use of natural resources as shown by the UNEP report on the exploration activities of oil mineral resources in the Ogoni land, more particularly considered below. ${ }^{4}$ It has also, been rightly

\footnotetext{
${ }^{1}$ https://www.unenvironment.org/about-un-environment/why-does-un-environment-matter, visited on the $21^{\text {st }}$ day of January, 2020.

${ }^{2}$ For key documents in this discussion see www.unisdr.org/2005/ HFdialogue/backdocs.htm.

Ibid.

${ }^{4}$ Ibid.
} 
stated, in our view that, given the analysis above that any genuine efforts to achieve MDG 7 is challenged by the unique features of this goal, especially the diversity of its targets. "The targets are heterogeneous, covering both human development and environmental issues without proper integration; [and] none of the environment-related targets were quantitatively specified." ${ }^{1}$ Furthermore, Goal 7, appears also to cover only a subset of the many challenging environmental issues that need to be addressed as shown in the UNEP report of Ogoni where the people are battling daily with the adverse effects of both air, aquatic and land pollution due to the activities of multinational oil companies and related factors in that region of the world. The mention of "carbon dioxide (CO2) emissions" and climate change issues in MDG 7 gives a clear pointer that more attention needs to be given to the activities leading to carbon dioxide (CO2) emissions and their in impact on climate change and its threats on humanity globally. This shows that the Rio principle of Common but Differentiated Responsibility (CBDR), is applicable under MDGs 7.

Efforts have protecting environment globally within the period of 2000-2015 shows that nations of the world are not only responding to the demands of MDGs 7 through the instrumentalist of (i) other regional initiatives; (ii) multilateral agreements, such as the UNFCCC, the Convention on Biological Diversity (CBD), the United Nations Convention to Combat Desertification (UNCCD) and the Convention on Wetlands (Ramsar Convention); and (iii) spontaneous responses of individuals, communities, non-governmental and civic organizations, business organizations, and nations to growing environmental threats. Expertise reviews have classified environmental protection issues covered in MDG 7 into four major groups ${ }^{2}$ namely: (i) forests; (ii) atmospheric issues; (iii) drinking water, sanitation, and slums and (iv) land, water and biodiversity issues. The UNEP created a model of the factors influencing levels of human losses from natural hazards at the global scale, for the period 1980-2000. Because of the importance of the work done by UNEP in this area, it is offer to quote in extensor the mode designed by the UNEP for the UNDP as a building block for Disaster Rick Index in monitoring the evolution of risk as follows:

"Assessing which countries are most at risk requires considering various types of hazards, such as droughts, floods, cyclones and earthquakes. These four hazards were tested with a model of population distribution in order to estimate human exposure before assessing risk. Human vulnerability was measured by comparing exposure with selected socio-economic parameters. The model evaluates to what extent observed past losses are related to population exposure and vulnerability. The UNISDR has been working on ways to measure implementation of the Hyogo Framework and progress towards disaster risk reduction, with a target date of 2015. In 2005, they proposed 81 indicators for measuring the Hyogo Framework. The framework identified five priority areas in which to develop indicators: policy and institutional aspects; understanding risk; knowledge management and education; reducing underlying risks; and strengthening response. A more recent UNISDR/ World Meteorological Organization (WMO) "Thematic Think Piece” (2012) argues that global goals and targets for disaster risk reduction and resilience raise the profile of the issues. Goals, targets and indicators should relate as closely as possible to human development indices, especially as vulnerability increases. Therefore, goals and targets for risk reduction at the global level are based on the measurement and estimation of either mortality or economic loss suffered because of the impact of natural hazards on vulnerable populations and assets. "3

To properly situate this paper a good work UNEP and its study terms have done around the globe, it is important to highlight a picture of the several views made on the environmental situation on the Ogoni people and our argument that the indigenous people of Ogoni fight squarely to a development of a community that is "resilient" as contemplated under MDGs 7 and further adumbrated by UNEP and its agencies. In the words of Late Ken SaroWiwa, who captured the adverse environmental effects of oil mineral exploration and it adverse impacts on Ogoni land particularly before the visit of UNEP to Ogoni land:

"Drilling of crude oil began in Ogoni land some thirty five years ago, making it one of the earliest areas from which crude oil was produced in Nigeria. The country's first oil refinery is in Ogoni land, at Eleme. So is, the Onne fertilizer plant, NAFCON. Since 1958, the contribution of crude oil to the national income has grown in leaps and bounds. Today, it contributes over 90\% of the country's export earnings. At the same time, the impact of oil production on the environment of this predominantly rural area has grown extensively. Not only have large tracts of farm land and fishing water been lost to drilling, but also the pollution arising from accident spillage of crude oil has destroyed marine life and made many hectares of farmland unsuitable for cultivation. The reckless dumping of usually toxic by-products of oil drilling and refinery, often in fresh water used for drinking, fishing and other household activities. On the other hand, the percolation of wastes from the oil industry into the soil contaminates ground water. At the same time, gas flaring in the vicinity of human dwellings and high-pressure oil pipelines forming a mesh across farmlands, have been conducive to acid rain, deforestation and destruction of wildlife. The international petrochemical giant, Shell dominates operations in Ogoni land as it does the entire Nigerian petroleum industry. The company's environmental record in developing countries is controversial, as

\footnotetext{
${ }^{1}$ Ibid.

${ }^{2}$ Ibid.

${ }^{3}$ Ibid.
} 
was demonstrated by a Channel Four documentary, 'Heat of the Moment' shown in Britain in the autumn of 1992. ${ }^{1}$

The above and several other reports of environmental degradation in the lands of the indigenous people of Ogoni land led to invitation of the UNEP to carry out an environmental assessment of the said land and the impacts of pollution on the lives of the native people. It is sad however that, several years after the assessment by UNEP and the generation of a report showing the dangers in the environment where the Ogoni people lives, not much has been done to deal with the problems contained in the UNEP report, portion of which are reproduced and discussed below.

As stated above, this segment of the paper will now concentrate on the particulars of the UNEP report on Ogoni land, the findings of UNEP on: Contaminated Soil, Groundwater, Vegetation, Aquatic, public health, Institutional issues and oil industry practices etc. which was captured on the said report and dealt with in an earlier article written by the author but reproduced hereunder for emphases: According to the United Nations Environment Programme Report (UNEP), ${ }^{2}$ Ogoni land is a region covering some 1,000 km2 in the south-east of the Niger Delta basin. It has a population of close to 832,000 , according to the 2006 National Census, consisting mainly of the Ogoni people. The region is divided administratively into four local government areas: Eleme, Gokana, Khana, and Tai. Traditionally the area is formed by six kingdoms (Babbe, Eleme, Gokana, Ken-Khana, Nyo-Khana and Tai) with His Majesty King Godwin N.K. Gininwa as the area's Paramount Ruler.

\subsection{The particulars of the UNEP report in Ogoni land}

According to Achim Steiner, the report contains how UNEP carried out their work, where samples were taken and the findings made for a period of 14-months. At this period, the UNEP team examined more than 200 locations, surveyed $122 \mathrm{kms}$ of pipeline rights of way, reviewed more than 5,000 medical records and engaged over 23,000 people at local community meetings. Detailed soil contamination investigations were conducted at 69 sites. Altogether more than 4,000 samples were analyzed, including water taken from 142 groundwater monitoring wellss drilled specifically for the study and soil extracted from 780 boreholes. The UNEP 'Environmental Assessment report on Ogoni land' was released in August, 2011."3

\subsection{The Findings Of UNEP ${ }^{4}$}

Several findings which were made by UNEP are stated hereunder, in the words of UNEP in the areas of contaminated soil/groundwater, vegetation, aquatic life, public health, institutional issues and oil industry practices etc.

Contaminated Soil and Groundwater: The report concluded that 'pollution of soil by petroleum hydrocarbons in Ogoni land is extensive in land areas, sediments and swampland. Most of the contamination is from crude oil although contamination by refined product was found at three locations. The assessment found that there is no continuous clay layer across Ogoni land, exposing the groundwater in Ogoni land (and beyond) to hydrocarbons spilled on the surface. In 49 cases, UNEP observed hydrocarbons in soil at depths of at least $5 \mathrm{~m}$. This finding has major implications for the type of remediation required. At two-thirds of the contaminated land sites close to oil industry facilities which were assessed in detail, the soil contamination exceeds Nigerian national standards, as set out in the Environmental Guidelines and Standards for the Petroleum Industries in Nigeria (EGASPIN). At 41 sites, the hydrocarbon pollution has reportedly reached the groundwater at levels in excess of the Nigerian standards as per the EGASPIN legislation. The most serious case of groundwater contamination is at Nisisioken Ogale, in Eleme LGA, close to a Nigerian National Petroleum Company product pipeline where an $8 \mathrm{~cm}$ layer of refined oil was observed floating on the groundwater which serves the community wells'.

Vegetation: On vegetation, UNEP found out that 'oil pollution in many intertidal creeks has left mangroves denuded of leaves and stems, leaving roots coated in a bitumen-like substance sometimes $1 \mathrm{~cm}$ or more thick. Mangroves are spawning areas for fish and nurseries for juvenile fish and the extensive pollution of these areas is impacting the fish life-cycle. Any crops in areas directly impacted by oil spills will be damaged, and root crops, such as cassava, will become unusable. When farming recommences, plants generally show signs of stress and yields are reportedly lower than in non-impacted areas. When an oil spill occurs on land, fires often break out, killing vegetation and creating a crust over the land, making remediation or re-vegetation difficult. Channels that have been widened and the resulting dredged material are clearly evident in satellite images, decades after the dredging operation. Without proper rehabilitation, former mangrove areas which have been converted to bare ground are being colonized by invasive species such as nipa palm (which appears to be more resistant to heavy hydrocarbon pollution than native vegetation). In Bodo West, in Bonny LGA, an increase in artisanal refining

\footnotetext{
${ }^{1}$ Quoted in Odje, A.M: The Challenges of True Federalism and Resource Control in Nigeria (Benin, Quadro Impressions Limited, 2002) P. 514.

${ }^{2}$ See pages $22-24$ of the report.

${ }^{3}$ See the United Nations Environment Programme. (C) 2011, United Nations Environment Programme. ISBN: 978-92-807-3130-9, Job No.: DEP/1337/GE. United Nations Environment Programme, p. 2.

${ }^{4}$ See pages 9-12 of the executive summary of the UNEP report on environmental assessment of Ogoni land sited above.
} 
between 2007 and 2011 has been accompanied by a 10\% loss of healthy mangrove cover, or 307,381 m2. If left unchecked, this may lead to irreversible loss of mangrove habitat in this area.

Aquatic: The UNEP investigation also found out that 'the surface water throughout the creeks contains hydrocarbons. Floating layers of oil vary from thick black oil to thin sheens. The highest reading of dissolved hydrocarbon in the water column, of $7,420 \mu \mathrm{g} / \mathrm{l}$, was detected at Ataba-Otokroma, bordering the Gokana and Andoni LGAs. Fish tend to leave polluted areas in search of cleaner water, and fishermen must therefore also move to less contaminated areas in search of fish. When encountered in known polluted areas, fishermen reported that they were going to fishing grounds further upstream or downstream. Despite community concerns about the quality of fish, the results show that the accumulation of hydrocarbons in fish is not a serious health issue in Ogoni land but that the fisheries sector is suffering due to the destruction of fish habitat in the mangroves and highly persistent contamination of many of the creeks, making them unsuitable for fishing. Where a number of entrepreneurs had set up fish farms in or close to the creeks, their businesses have been ruined by an ever-present layer of floating oil. The wetlands around Ogoni land are highly degraded and facing disintegration. The study concludes that while it is technically feasible to restore effective ecosystem functioning of the wetlands, this will only be possible if technical and political initiatives are undertaken'.

Public health: The findings of public health by the same report shows that 'the Ogoni community is exposed to petroleum hydrocarbons in outdoor air and drinking water, sometimes at elevated concentrations. They are also exposed through dermal contacts from contaminated soil, sediments and surface water. Since average life expectancy in Nigeria is less than 50 years, it is a fair assumption that most members of the current Ogoni land community have lived with chronic oil pollution throughout their lives. Of most immediate concern, community members at Nisisioken Ogale are drinking water from wells that is contaminated with benzene, a known carcinogen, at levels over 900 times above the World Health Organization (WHO) guidelines'. The report further stated that this 'contamination warrants emergency action ahead of all other remediation efforts. Hydrocarbon contamination was found in water taken from 28 wells at 10 communities adjacent to contaminated sites. At seven wells the samples are at least 1,000 times higher than the Nigerian drinking water standard of $3 \mu \mathrm{g} / \mathrm{l}$. Local communities are aware of the pollution and its dangers but state that they continue to use the water for drinking, bathing, washing and cooking as they have no alternative. Benzene was detected in all air samples at concentrations ranging from 0.155 to $48.2 \mu \mathrm{g} / \mathrm{m} 3$. Approximately 10 per cent of detected benzene concentrations in Ogoni land were higher than the concentrations WHO and the United States Environmental Protection Agency (USEPA) report as corresponding to a 1 in 10,000 cancer risk. Many of the benzene concentrations detected in Ogoni land were similar to those measured elsewhere in the world, given the prevalence of fuel use and other sources of benzene. However, the findings show that some benzene concentrations in Ogoni land were higher than those being measured in more economically developed regions where benzene concentrations are declining because of efforts to reduce benzene exposure'.

Institutional issues: On institutional issues UNEP stated that 'first issued in 1992, the EGASPIN form the operational basis for environmental regulation of the oil industry in Nigeria. However, this key legislation is internally inconsistent with regard to one of the most important criteria for oil spill and contaminated site' management - specifically the criteria which trigger remediation or indicate its closure (called the 'intervention' and 'target' values respectively). The study found that the Department of Petroleum Resources (DPR) and the National Oil Spill Detection and Response Agency (NOSDRA) have differing interpretations of EGASPIN. This is enabling the oil industry to close down the remediation process well before contamination has been eliminated and soil quality has been restored to achieve functionality for human, animal and plant life. It stated further that 'the Nigerian Government agencies concerned lack qualified technical experts and resources. In the five years since NOSDRA was established, so few resources have been allocated that the agency has no proactive capacity for oil-spill detection. In planning their inspection visits to some oil spill sites, the regulatory authority is wholly reliant on the oil industry for logistical support. The oilfield in Ogoni land is interwoven with the Ogoni community. The fact that communities have set up houses and farms along rights of way is one indicator of the loss of control on the part of the pipeline operator and the government regulator. The UNEP project team observed hundreds of industrial packing bags containing 1,000-1,500 $\mathrm{m} 3$ of waste, believed to be cuttings from oil drilling operations, dumped at a former sand mine in Oken Oyaa in Eleme LGA. The open disposal of such waste in an unlined pit demonstrates that the chain of custody in the region between the waste generator, transporter and disposal facility is not being followed.

Oil industry practices: The study concludes that the control, maintenance and decommissioning of oilfield infrastructure in Ogoni land are inadequate. Industry best practices and SPDC's own procedures have not been applied, creating public safety issues. Remediation by enhanced natural attenuation (RENA) - so far the only remediation method observed by UNEP in Ogoni land - has not proven to be effective. Currently, SPDC applies this technique on the land surface layer only, based on the assumption that given the nature of the oil, temperature and an underlying layer of clay, hydrocarbons will not move deeper. However, this basic premise is not sustainable as observations made by UNEP show that contamination can often penetrate deeper than $5 \mathrm{~m}$ and has reached the 
groundwater in many locations. Ten out of the 15 investigated sites which SPDC records show as having completed remediation, still have pollution exceeding the SPDC (and government) remediation closure values. The study found that the contamination at eight of these sites has migrated to the groundwater. In January 2010, a new Remediation Management System was adopted by all Shell Exploration and Production Companies in Nigeria. The study found that while the new changes are an improvement, they still do not meet the local regulatory requirements or international best practices.

0.4. The Hydrocarbon Remediation Project Report (HYPREB) On The Ogoni Environment Of Nigeria, its Establishment, Functions, Achievements and Perceptions ${ }^{1}$

As published in the Federal Government gazette, HYPREP was established under the Federal Ministry of Environment ${ }^{2}$ to achieve the under listed objectives in Ogoni land and other impacted communities:

1. Determine the scope, means and modalities of remediation of soil and ground water contamination in impacted communities as maybe recommended by HYPREP Governing Council and remedy them.

2. Enhance local capacity for better environmental management and promote awareness of sound environmental management as well as ensure livelihoods and sustainable development.

3. Ensure security and promote peace building efforts in impacted communities.

4. Strengthen governance, transparency and accountability in the region.

The HYPREP established the project coordinating office, a governing Council and board of trustee with an operative office at No. 350 Aba Road, Port-Harcourt, Rivers State Nigeria.

\subsection{The scope of work of HYPREP ${ }^{3}$}

The scope of work of HYPREP as shown in the instrument cited above include the following:

i. Investigate, map and evaluate hydrocarbon polluted communities and sites in Nigeria referred to it by the National Oil Spill Detection Response Agency (NOSDRA) or the Federal Ministry of Environment in collaboration with the Department of Petroleum Resources (DPR) and make recommendations to the Federal government.

ii. Implement the recommendations of the United Nations Environment Programme (UNEP) Report on Environmental Restoration of Ogoni land (UNEP Report) as directed by the HYPREP Governing Council.

iii. Initiate, and develop work programmes aimed at restoring all hydrocarbon impacted communities and sites referred to HYPREP.

iv. Undertake a comprehensive assessment and mapping of all environmental issues associated with hydrocarbon pollution, in collaboration with NOSDRA.

v. Provide guidance data to undertake remediation of contaminated soil and ground water in Ogoni land and such other impacted communities as may be referred to it.

vi. Technically evaluate alternative technologies to be employed to undertake remediation of contaminated soil and ground water.

vii. Make recommendations for responding to future environmental contamination from hydrocarbons.

viii. Ensure full environmental recovery and restoration of Ogoni ecosystem services for Ogoni people and other impacted communities.

Acclaimed Achievements of HYPREP as at the years $2016-2019^{4}$

a) Project Activities: To ensure proper Stakeholder participation in the Programme, four (4) Ad hoc Committees were inaugurated on 24 May 2016 to commence preparation for activities on the clean-up project. Each committees had 16 members drawn from all the local governments in Ogoni land communities. The committee are:

1. Committee for the Centre of Excellence and the Integrated Contaminated Soil Management Centre.

2. Committee for Training and Livelihood.

3. Committee on Communication and Strategy.

4. Committee on Emergency Measures. The above committees setup by HYPREP submitted their reports on 2nd September 2016.

On 16th February, 2017 the ground-breaking ceremony for the construction of the Integrated Contaminated Soil Management Centre in Bori New City in Khana Local Government Area of Ogoni land and the project for Demonstration of Clean-up Technology was also launched at a site in Kwawa, Khana Local Government Area of Ogoni land, with demonstration projects also starting at eleven (11) other sites identified in the four Local Government Areas of Ogoni land. It is submitted at this point that the various committee setup by HPREP do not appear to have the capacity or the required finances to enable them carry out the functions they are created to serve.

\footnotetext{
${ }^{1}$ See www.hyprep.gov.ng, accessed on the $11^{\text {th }}$ day of October, 2018.

${ }^{2}$ As published in the Federal Government gazette No. 176, Vol. 103 of December, 2016

${ }^{3}$ Ibid.

${ }^{4}$ Ibid
} 
Furthermore it shows the lack of political will, on the side of the Federal Government of Nigeria to implement the UNEP report which formed the bases, for the setting up of HYPREP in Ogoni land.

However, Rivers State Government Nyesom Wike has said that "the protracted implementation of the United Nations Environment Programme (UNEP) report on Ogoni is a grand fraud and deception. Wike, who made this assertion while addressing the 108 and 109 general session of Rivers State Council of Traditional Rulers in Port Harcourt, urged monarchs in the state to lend their voices in condemning the neglect or Rivers State by the Federal Government. He said it was disheartening that 28 months after the Federal Government launched the Ogoni land clean-up, they were yet to commence the exercise as recommended by UNEP. According to him, it was time the people lent their voices more forcefully to the neglect of the state by the Federal Government, the devastation of the environment by the oil companies, the grand fraud and deception in the Ogoni clean-up exercise and the call for economic justice and fiscal federation. In addition he also said that the state owned security outfit, Rivers State Neighbourhood Safety Agency, would soon commence operation for the primary purpose of detection and prevention of crimes across the state." 1

10. Emergency Measures Recommended by UNEP Report On Ogoni Land ${ }^{2}$

The report identifies eight emergency measures which, from a duty of care point of view, warrant immediate action. 1 informed of the danger.

2. Provide adequate sources of drinking water to those households whose drinking water supply is impacted.

3. People in Nsisioken Ogale who have been consuming water with benzene over 900 times the WHO guideline are recorded on a medical registry and their health status assessed and followed up.

4. Initiate a survey of all drinking water wells around those wells where hydrocarbons were observed and arrange measures (1-3) as appropriate based on the results.

5. Post signs around all the sites identified as having contamination exceeding intervention values warning the community not to walk through or engage in any other activities at these site.

6. Post signs in areas where hydrocarbons were observed on surface water warning people not to fish, swim or bathe in these areas.

7. Informed all families whose rainwater samples tested positive for hydrocarbons and advised them not to consume the water.

8. Mount a public awareness campaign to warn the individuals who are undertaking artisanal refining that such activities are damaging their health.

b) Emergency Measures Reportedly Undertaken by HYPREP in Ogoni Land ${ }^{3}$

1. Water: The report by HYPREP showed that the body, did setup a four man committee on Water to identify and evaluate existing water facilities in the four local government areas of Ogoni. The said report was turned in reportedly after a thorough and painstaking tour of those water facilities in Ogoni land. The report revealed obsolete and abandoned water infrastructure and the quality of water from some functioning facilities do not meet the WHO potable water requirements.

2. Updates of Baseline Data of UNEP Report: The UNEP report was submitted to the Federal Government in 2011 and between then and now, there have been changes in the nature and characteristics of the impacted sites that were studied in the report. In addition, there have been other impacted sites that were not captured in the UNEP report. In collaboration with UNEP, we are about to commence the process of scoping and updating all sites previously assessed including newly impacted sites and others not previously captured by UNEP in Ogoni land.

3. Health Impact Assessment Study: One of the other key recommendations by the UNEP report is the conduct of a health impact study in the impacted communities of Ogoni to ascertain whether there is a link between some disease pattern and oil pollution in the community. In this regard we had on 10th July, 2017 advertised in some Nigerian dailies for the expression of interest and invitation for the pre-qualification for the implementation Health Impact Assessments, Immediate assessment and carrying out the rehabilitation of existing water facilities in Ogoni land, Design and construction of comprehensive water schemes in Ogoni land and Environmental Consultancy to carry out Scoping and assessment of oil impacted sites assessed by UNEP in Ogoni land. The bids were opened on Monday 24, July 2017. A total number of Two Hundred and Three (203) bids were received and opened. We are partnering with the UN system especially WHO in this regard.

4. Medical Outreaches:

a. Over 3,000 Ogoni indigenes have benefited from the free medical outreach organised by the Hydrocarbon Pollution Remediation Project, (HYPREP). The HYPREP Coordinator, Dr. Marvin Dekil, said the health outreach was significant to the clean-up exercise in Ogoni land.

\footnotetext{
${ }^{1}$ See The Guardian, Tuesday, November 6, 2018, P.15

${ }^{2}$ See page 13 of the executive summary of the UNEP reports on environmental assessment of Ogoni land.

${ }^{3}$ Ibid.
} 
b. That the HYPREP has reportedly carried out two phases of medical intervention in four Local Government Areas of Ogoni land in the year 2016 and those who were diagnosed with painful but treatable medical conditions due to limited access to health facilities and lack of finances were treated by the medical team and that the process of the clean-up has been consistent, that we are suppose - to do within the law but expressed the hope that a review on the operations and that emergency measures like the provisions of water, have being opened and more demonstration project sites, health impact assessment have also been carried out among others. ${ }^{1}$

5. Current realities of the activities of HYPREP on Ogoni Land and reactions from the people of Nigeria On the $17^{\text {th }}$ day of September, 2019 HYPREP released a report captioned "MILITARY OPERATIONS IN OGONILAND; HYPREP POSITION." Which contained the following:

a) that information available to HYPREP indicated that there was a military presence in Ogoniland and that the "military intervention in Ogoniland is in response to calls by Ogoni leaders on Government to end the spate of destruction to life and property in the area by rival cult groups vying for supremacy." It stated further that "HYPREP does not control the security in the State or Ogoniland and, as such cannot command the deployment of security personnel for any operation [and that] "the military action has stalled their operations in the Local Government Areas where the raid for illegal arms and culprits is being carried out." The report further stated that HYPREP wished it ended soon so that they could resume work. The body then went further to "assure the good people of Ogoniland that, HYPREP will work in line with the objectives assigned to it in the gazette and will by its activities and actions ensure security and enhance peace building and promote peace building efforts in the region."

b) HYPREP further pledged their "commitment to carrying out quality remediation work in Ogoniland as we have mobilized contractors to twenty one lots across the four Local Government Areas of Eleme, Tai, Gokana and Khana with plans at advanced stage to start the batch one, second phase of remediation of complex sites" and that the body was at the "concluding stage of plans to providing potable water in impacted communities of Ogoniland that rehabilitation of moribund water facilities in the area was yet to be done but promised that: the "livelihoods program for women will soon be on stream" and that a further provision "for a batch of four hundred trainees of one hundred persons per Local Government Area" was in the works. HYPREP, then appealed "to the people of Ogoni to cooperate with and support the Project as it strives to fully implement the recommendations in the United Nations Environment Programme (UNEP) Report on the clean-up of their land."'2

The above chronicled events or aspirations of the HYPREP in Ogoniland shown a clear lack of seriousness on the part of HYPREP created by the Federal Government of Nigeria to avert the environmental crises on the environment and livelihood of the Ogoni people, who have suffered, for decades following the activities of multinational oil companies in their native soil. It is summited that, the Federal Government immediately dissolves HYPREP and set up a more professional and proactive body to address the urgent needs of the Ogoni people and their survival in their native lands now effectively poisoned by the activities of the said oil companies and the Federal Government of Nigeria.

c) On the 6 day of January, 2020 Nigerian authoritative Guardian newspaper come up with screaming head line as follows: "Ogoni cleanup may be wasted effort due to fresh pollution in Bori.",3

The said report quoted Project Coordinator of Hydrocarbon Pollution Remediation Project (HYPREP), Dr. Marvin Dekil, as follows:

i. that the $\$ 1$ billion earmarked for the cleanup of Ogoniland in the first five years of the exercise may amount to a waste because of the ongoing illegal oil bunkering and artisanal refining. The said coordinator who was speaking this on the topic: "re-pollution in Bori" during the International Day of World Indigenous People stated among other things that "our effort to cleanup Ogoniland will amount to nothing if after investing so much resources and time to remediate the land, it is again re-polluted by the activities of illegal bunkering and refining." ii. That the Movement of the Survival of the Ogoni People (MOSOP) and the communities should dissuade the youths from activities, which danger to the health, environment and economy, so that when Ogoniland is cleaned up, it would remain unpolluted for future generations.

iii. Saluted the Ogoni people for their resilience and commitment to non-violent struggle, saying that United Nations and the Federal Government have recognized Ogoni struggle for which HYPREP was set up in response to demands for a clean-up of the environment.

iv. That HYPREP's promise to mobilise remediation contractors to the sites had been fulfilled, as they were presently working on lots in the four council areas of Ogoniland.

v. That in spite of the several communal and environment factors that hindered HYPREP, work has progressed.

vi. In most of the sites, contractors are excavating and treating contaminated soils and some have even

\footnotetext{
Ibid.

${ }^{2}$ This released which was signed by one Ekaete Um (head of information) and was published on the $17^{\text {th }}$ of September, 2019. See details on https://hyprep.gov.ng/military-operations-in-ogoniland-hyprep-position/, visited on the $21^{\text {st }}$ day of January, 2020.

${ }^{3}$ See the Guardian, Monday, January 6, 2020, South-South News, Pg. 9. From kelvin Ebiri, Port Harcourt.
} 
completed the process of excavation and are back filling treated soils.

vii. That HYPREP would soon progress to the complex sites where more work was required resulting in numerous economic and social prospects for the Ogoni people in the areas of job opportunities, skill acquisition from HYPREP livelihoods training programme and specialized remediation work in the field.

In the said event, Legborsi Pyagbara (MOSOP President) also warned that climate change crisis should be taken seriously in the country, adding that is has one of the biggest challenges of the $21^{\text {st }}$ century such that the government and people could not continue to ignore it. ${ }^{1}$ However, it is very important to consider further the very cogent issues renowned environmentalist have raised on the slow pace of the clean-up activities of HYPREP in Ogoni land as follows: ${ }^{2}$

a. Four years into the Hydrocarbon Pollution Remediation Project (HYPREP), initiated by the Federal Government to clean up contaminated Ogoni land in Rivers State, the exercise is dogged in transparency issues. The Federal Government flagged off the remediation of contaminated sites in Ogoni land in 2016. The government had through the Nigeria National Petroleum Corporation, and multi-national oil companies mobilized \$180 million for the exercise.

b. A total of 21 contractors were picked for the clean-up remediation exercise but that the procedure employed by the government has been condemned by critical stakeholders and environmentalists questioning the process adopted to remedy the sites.

c. In the year 2019, a group, the Civil Society Legislative Advocacy Centre (CISLAC), said the status of HYPREP in terms of its structure, independence, funding, effectiveness, capacity as well as perception of sluggishness due to bureaucracy, politicization, low responsiveness has affected the clean-up exercise.

d. According to CISLAC, the exercise is now bugged with identity crisis, procedures, processes and overheads. Perception of corruption, lack of transparency and accountability, complex decision making, internal crisis of choice between Ogoni and the Niger Delta.

e. The programme Manager, Mr. Kolawole Banwo, who provided an overview of the UNEP report on Ogoniland at an interaction in Lagos, said HYPREP is now seen as a HY-BRID, made up a specific programme for the Ogoniland clean-up.

f. He also noted lack of no sequence of action and prioritization of activities and cost management as well as adherence to original in the process.

g. The fatalities occasioned by pollution in Niger Delta, particularly Ogoni had called for serious attention to save lives and property.

h. That there is need to revisit, and where necessary remediate identified sites since the programme is eight years behind after the report itself was first launched in 2011 and 63 years late after the first oil spill happened in Oloibiri in 1953.

i. The Federal Government flagged off the remediation of contaminated sites in Ogoni Land in 2016 but not much appears to have been done in that direction.

j. That the wellbeing of the people in Ogoni and the Niger Delta at large is to the least pathetic. Life expectancy has dropped to 40, livelihoods destroyed, inhabitants consume contaminated water 900 times above the World Health Organization (WHO) standards.

k. That festival of funerals in the region has become very worrisome, all due to pollution and exposure to environmental hazards. This call for the urgent need to review the remediation techniques, repair, maintain and decommission non-producing facilities.

1. The duty of care point of view upon which the emergency measures are based imposes not just a moral but a legal obligation to prevent harm or compensate victims.

m. The 25-year long journey and struggle for the clean-up of Ogoni land and the Niger Delta Region is a challenge to our shared humanity. It is about the lives of real people whose only offence is that petroleum resources which drive Nigeria's economy are found in their land.

$\mathrm{n}$. That the people must keep asking right questions, applying the right pressure and speaking out. With the professionalism, courage and persistence of the press we will achieve more and faster. We must do more to get our government to clean up Ogoni now and other parts of the Niger Delta region of Nigeria.

o. There is a comprehensive health audit apart from the health outreaches by HYPREP.

The above chronicled events or aspirations and views expressed by environmentalists and civil society organizations on the activities of HYPREP in Ogoniland shown a clear lack of seriousness on the part of HYPREP created by the Federal Government of Nigeria to avert the environmental crises on the environment and livelihood of the Ogoni people of the Niger Delta region of Nigeria, who have suffered, for decades following the activities of multinational oil companies in their native soil. It is summited that, the Federal Government immediately dissolves HYPREP, declare a state of emergency on the environment of the Ogoni people particularly and in the

${ }^{2}$ See the Guardian, Monday, January, 2020, The Environment. Pg. 34. Environmentalists urge definite approach in Ogoniland clean-up by Bertram Nwannekanma and victor Gbonegun.
} 
Niger Delta, in general and take up more professional and proactive steps to address the urgent needs of the Ogoni people and their survival in their native lands now effectively poisoned by the activities of multinational oil companies and the Federal Government of Nigeria.

\section{CONCLUSION}

As stated by this author in an earlier article "there is no doubt that a lot has gone wrong in Ogoni land particularly and the Niger Delta region, generally. For sustainable development, justice for Nigeria to know equity and peace to reign, Nigeria must quickly implement the UNEP report it is worthy of note that, the Buhari - led Federal Government of Nigeria appropriately approved the setting up of a board of trustees to commence the process of implementing the report and approval of the amendment of the Official Gazette establishing the Hydrocarbon Pollution Restoration Project (HYPREP), to reflect a new governance framework and a new implementation template. But more need to be done and ought to be done now. Based on the above the following recommendations gleaned from the above analyses are made.

\section{RECOMMENDATIONS}

1. The author calls on the United Nations, national and international non-governmental agencies to prevail on the Nigerian government, without further delay, to implement all the recommendations of the UNEP report on Ogoni land, as this is the only pathway towards realizing the laudable aspirations implied in goal 7 of the MDGs for nations of the world and averting further environmental disasters and threats to human lives in the area.

2. A serious and scientific medical auditing of the entire Ogoni land and indeed the Niger Delta region be undertaken to find out the patterns of illnesses and their connection between the environmental conditions so that a holistic medical response that would not just address the current situation, but future occurrences can be made or will be made.

3. HYPREP, should as a matter of urgency, provides alternative water sources for the communities in Ogoniland and stop depending on Rivers State water board or its schemes in the Rivers State of Nigeria.

4. Recent visits by researchers to one of the locations in Eleme area shows sadly that the soil was contaminated up to a depth of 5-metres in the UNEP report but the actual excavation now shows that it is now up to 7-metres meaning that as time goes on, the contamination is getting deeper.

5. As rightly observed by the Director of the ecological think tank, health of Mother Earth Foundation, Nnimmo Bassey, the Ogoni land requires a lot of preliminary works to get the clean up off the ground, the delineation, quantification setting up of the key performance indicators and how to know that what needs to be done has not be done.

6. HYPREP needs to also commence the clean-up in the more easily reachable and the less polluted locations. 